\title{
Settlers and Laborers: \\ The Afterlife of Indenture in \\ Early South African Indian Writing
}

\author{
NIENKE BOER \\ Yale-NUS College \\ nienke.boer@yale-nus.edu.sg
}

\begin{abstract}
As part of a growing scholarly corpus on African literature within an Indian Ocean framework, Gaurav Desai, in his recent book on writing by South Asians in East Africa, asks: "How, and under what conditions, do settlers become natives?" (13). While discussions of Indian South African writing have centered around recent novels, I take up Desai's question in relation to earlier generations of Indian South African writing, specifically Ansuyah R. Singh's novel, Behold the Earth Mourns, and Mohandas K. Gandhi's Autobiography: The Story of My Experiments with Truth. I argue that these authors wanted to distance themselves from indenture and embrace a different narrative: that of the settler. They thus employ the tropes of settler writing to escape the constraints, both temporal and narrative, imposed by the indenture contract. However, the specter of the contract introduces the rhetoric of law into their work, at odds with the sentimental language associated with settler narratives.
\end{abstract}

$\mathrm{F}$ ollowing the abolition of the slave trade within the British Empire in the nineteenth century, more than 1.3 million Indian subjects of the British Raj migrated to other parts of the world under indenture contracts, with 152,184 indentured laborers traveling to the South African colony of Natal between 1860 and 1909. This wave of imperially regulated migrations to South Africa was followed by a second, smaller group of Indian traders, known as "passenger Indians." In Commerce with the Universe: Africa, India, and the Afrasian Imagination, Gaurav Desai examines fictional and autobiographical texts by South Asians living in East Africa, engaging with the question first posed by Mahmood Mamdani: "How, and under what conditions, do settlers become natives?" (13). ${ }^{1}$ Theorists have scrutinized the narrative tropes of "settler writing," as delineated by J. M. 
Coetzee's White Writing: On the Culture of Letters in South Africa, in South Africa and other settler colonies, but Desai's work introduces a new dimension to the debate by looking at would-be settlers who are not "white" in the sense Coetzee's book implies. Desai's study is part of a growing body of scholarship designed to address what Isabel Hofmeyr calls "one major fault line of Indian Ocean studies, namely the prominence of India as opposed to the invisibility of Africa" (101). Turning specifically to Ansuyah R. Singh's novel, Behold the Earth Mourns, and Mohandas K. Gandhi's autobiography, The Story of My Experiments with Truth, alongside other memoirs and legal and biographical documents, I look at how the indenture system imposes itself on and shapes early Indian South African writing, despite the attempts by these authors to distance themselves from the contract by turning to the tropes of the settler novel.

Though a significant canon of Indian South African fiction now exists, the majority of the texts were written during the final years of apartheid and after the 1994 democratic election. ${ }^{2}$ Ansuyah R. Singh's text, Behold the Earth Mourns, published in 1960 in Cape Town to commemorate the centenary of the arrival of the first Indians in South Africa, is the first novel published by an Indian South African. The novel begins by introducing the Nirvani family, focalized on Krishnadutt Nirvani:

His children were the third generation of settlers in this southern land of sunshine and adventure. His father Nirvani had come out as a virile young trader accompanied by an inexperienced wife.... In the years of their life together she could have been strengthened by adversity, success and excitement-the trials and heartaches that they were faced with in a new country, undeveloped, raw, and unbuilt. (3-4)

By explicitly identifying her characters as "settlers," and in her descriptions, both of the landscape and the people "settling" it, Singh conforms to much of typical colonial writing. South Africa is described as "this southern land of sunshine and adventure," "a new country, undeveloped, raw and unbuilt." The new settlers are heroic, bravely confronting "trials and heartaches that they were faced with in a new country." Even the architecture of the house Nirvani builds is recognizably colonial: "Several porticos and verandahs supported by thick white columns surrounded the inner rambling house," while the garden consisted of "carpet-like lawns, orchards of mango, figs and citrus groves" (5). There is no indication of who performed the labor to establish these orchards, or acknowledgment that these fruit were not originally indigenous to South Africa (mangos, originally native to South Asia, were introduced to South Africa in 1860, when the first known mango plantation was established in Durban - this was the same year indentured laborers first arrived at Durban [Morton]). The question of who works the land is central to traditional settler writing: J. M. Coetzee comments on the necessary "occlusion of black labour from the scene" of white pastoral literature (White Writing 5). In Singh's description, and her novel in general, no mention is made of any labor taking place on the "sugar cane farm" (5) owned by Nirvani at all-both black African labor and, crucially, indentured South Asian labor are effaced.

In the first chapter, the Nirvanis have just received a letter informing them that they will have to vacate their house on the outskirts of Durban in the near future because of racial zoning laws. The two brothers, Srenika and Krishnadutt, 
react very differently. Krishnadutt, the elder, is a pragmatist: "We will have to apply our minds to this matter carefully. It needs a great deal of thought and perhaps it will not be so bad. Perhaps if we come to some compromise about the lands. . . . Incoherent emotionalism does not get us anywhere. We have to obey the rules and live on" (Singh 2-3). Krishnadutt is invested in following the letter of the law. In contrast to this, his younger brother, Srenika, reacts with so-called "incoherent emotionalism": "Don't you feel ... the aura of mystery, the sanctity, the precious meaning of our home, of their home-the very pulse that keeps people together, that protects men and women with the children from the world of harshness, from the changeable forces of nature?"(3). Although dismissed by his brother as "incoherent emotionalism," Srenika's stance allies his claim closely with that of typical settler narratives, where the family's deep bond to the land is seen as legitimating their ownership. The "precious meaning of home" is stable and timeless, opposed to the "changeable forces of nature." This is at first glance an unusual comparison-the time of nature is usually seen as stable, the referent against which to compare manmade rhythms. Srenika here extends the implicit conflict envisioned in the description of their typical settler house: nature is "raw, unbuilt" until the settlers tame it, such that the settlers impose order and stability onto the land. This comparison already suggests a certain chronotope, or time-space: one that is invested in erasing the history of the now-settled land and superimposing the history of a specific family onto it. ${ }^{3}$ Krishnadutt's argument, that "we have to obey the rules and live on," however, introduces an unexpected and aty pical note to what seems to be a typical settler narrative, as it suggests that the ownership claim on the land is contingent on rules and laws, not an emotional bond, and that these claims, and the meaning of home, can change. The affective rhetoric of the settler novel, invested in this notion of a stable, unchangeable relationship between one family and the land, is undercut-I would argue, deliberately_-by Singh's use of legalistic language throughout the text.

In South African legal history, the period between 1902 and 1936 involved the development and consolidation of a pluralistic common law legal system-one for whites, which followed a Roman-Dutch model, heavily influenced by English common law, and another for black South Africans, which was supposedly modeled on traditional or customary practices, but as filtered through the understanding of white lawmakers who often chose to interpret customary practice in the way most convenient to them. The main challenge that faced South African lawmakers was the need to maintain a facade of impartial justice and the rule of law, when, in practice, they were implementing extremely discriminatory racial policies. The presence of Indian settlers in South Africa troubled this already muddled dichotomy of African customary law and Roman-Dutch law. As the colonial legal historian Martin Chanock explains, "Because Asians could not, like Africans, be relegated to a different legal regime, but had to be discriminated against within and by the ordinary law, they posed many of the most difficult problems to South Africa's lawyers" (19). While Indians who had migrated under indenture contracts were governed, during the period of their contract, by laws specifically designed for this purpose, once the period of indenture expired, legal authorities had to pass new laws in order to maintain the difference between these would-be settlers and white settlers. Indentured labor was curtailed as a practice in the Union of South Africa in 1909, and so, by the end of 1915 (when the last of the five-year 
indenture contracts had come to an end), the laws written for indentured laborers were no longer relevant. Even before 1909, however, one can see discriminatory laws against non-indentured Indian immigrants coming into force. ${ }^{4}$ These laws, I argue, can be traced to the desire, on the behalf of the British rulers of the South African colonies, to return South Asian would-be settlers in South Africa to the control of the indenture contract. For example, the 1907 Asiatic Registration Act (with its accompanying paraphernalia of fingerprints and passes) seeks to return the Indian to the position of being an indentured laborer, who could not legally be more than a mile from his or her place of employment without a signed pass from an employer. ${ }^{5}$ When writers of South Asian descent turn to the tropes of colonial settler writing, they are thus explicitly resisting laws and statutes that seek to make it impossible for them to settle permanently in South Africa.

A text by an influential apartheid thinker, the sociologist Geoffrey Cronjé, on the "Asiatic Question," shows how racist ideologues viewed the presence of Indian settlers in South Africa. Published in 1946, Cronjé's treatise, Afrika sonder die Asiaat: Die blywende oplossing van Suid Afrika se Asiatevraagstuk [Africa without the Asiatic: The Lasting Solution to South Africa's Asiatic Question] is intended as a supplement to his earlier text, ' $n$ Tuiste vir die nageslag [A Home for the Posterity], which introduces Cronjé's plans for total race segregation. While placing Cronjé's Afrikaans writings next to Singh's novel may seem an unusual juxtaposition, Cronjé's concern with questions of tuiste (home, or homeland) and nageslag (posterity, or descendants) brings him into conversation with the notions of home and family introduced by Srenika in Behold the Earth Mourns. In the Preface to Afrika sonder die Asiaat, Cronjé sums up some of the problems the presence of Indian South Africans causes for race-based policy making:

Inderdaad is dit' $n$ ingewikkelde en "glibberige" vraagstuk wat geheel anders is as enige ander rassevraagstuk... Toe die naturelle—en kleurling—vraagstukke elders bespreek is, is daardie vraagstukke enersyds uit die oogpunt van die blankes beskou maar andersyds ook steeds uit die oogpunt van die naturelle en die kleurlinge onderskeidelik omdat hulle inheems is en nêrens anders as op hierdie vasteland ' $n$ tuiste sal vind nie. Kom ons egter by die Asiate- of Indiervraagstuk, dan kry ons te make met 'n rassegroep wat uitheems is en uitheems bly.

This is indeed a complicated and "slippery" [glibberige] question that differs completely from any other race-question. ... When we discussed the native and Colored questions elsewhere, those questions were considered on the one hand from the point of view of the whites, but on the other hand also from the point of view of the natives and the Colored people respectively because they are indigenous and won't find a homeland other than on this continent. When we get to the Asiatic or Indian question, however, we are dealing with a racial group that is alien and will remain alien. (4; all translations of Cronjé by the author)

Cronjé's argument ultimately concludes with an ambitious total repatriation scheme, after evaluating the more modest alternatives of local segregation (within South Africa) and total segregation (giving South Asians their own "homeland" elsewhere in sub-Saharan Africa) and concluding that these latter two would be just short-term solutions to the problem. Lawmakers contented themselves with legislating only for local segregation. Regardless, we can see why Cronjé's 
argument depends on this key point: that Indian South Africans are alien and will remain alien.

J. M. Coetzee, in an article entitled "The Mind of Apartheid: Geoffrey Cronjé, (1907-)," argues that, in reading Cronjé, "above all, we must be sensitive to his language" (3). Cronjé's use of the adjective "slippery" [glibberig] in the preface to Afrika sonder die Asiaat is telling. Coetzee does not address this appendix to ' $n$ Tuiste vir die nageslag in his analysis, but he points us to certain imagery that Cronjé is fond of using. Noteworthy in this context is Cronjé's use of the term "insypel" or "to seep in":

\footnotetext{
"Seep ... in" (Afr. insypel, insyfer) is another key term for Cronjé's imagination: variable in form in Afrikaans as in Dutch (sijpelen, zijpelen, siepelen, sieperen), he uses it in contexts where it easily changes places with its rhyme-word insluip, steal in: the secret bastard who tries to find a place in the white community, and the bed of a white woman, is "die sluwe in-sluiper," the sly stealer-in (77). The semantic nexus evoked is one of dark and treacherous fluidity. (Coetzee, "Mind of Apartheid" 10)
}

"Glibberig" falls within this same semantic nexus, of "dark and treacherous fluidity." The word can be applied to the Indian himself as Cronjé sees him, who slips (glip) into the country from outside and who is slippery in his careful evasion or misuse of the law. Chanock, writing on the legal position of Indians in South Africa, explains the frustrations of lawmakers when Indian lawyers learn to negotiate within the law and even use it against the intentions of the lawmakers. "These people are continually creeping beyond the intention of the law" (qtd. in Chanock 493), one authority complains. Another says: "[T]hey may have acted within the four corners of the law, but anyone will admit that what they did was done by means of subterfuge" (qtd. in Chanock 493). "Creeping beyond" belongs to this same set of vocabulary generated by the presence of Indians in South Africa. In Act 1 of 1897 in Natal, the "Immigration Restriction Act," a law aimed at limiting the immigration of "prohibited immigrants," persons who could not prove their written proficiency in "any European language" are classed along with prostitutes, pimps, felons, the insane, and, crucially, "anyone suffering from a loathsome or a dangerous contagious disease" as undesirable ("Act 1 of 1897" 1). The language of contagion is key here. "Glibberig" is etymologically related to the English word "glib" (which is Germanic in origin), a term also used by a magistrate to describe the arguments made in court by Mohandas K. Gandhi, who lived and practiced law in South Africa between 1893 and 1914: “I'm afraid it [intimidation] will continue so long as your friends are permitted to do what you so glibly term 'watching'" ("Trial of the Naidoos" 718). "Slippery," "glib," and contagious, "creeping beyond" the boundaries imposed by law, we can see how Indian would-be settlers were semantically constructed as insidiously threatening through the use of emotionally charged language.

Cronjé seems unaware of the irony of arguing for the repatriation of Indian South Africans because they are not indigenous to South Africa while at the same time taking for granted the position of white South Africans within South Africa. He makes no acknowledgement of the fact that whites do not have the same claim to indigeneity as natives and coloreds are accorded in the preface. Later in Afrika sonder die Asiaat, we read: 
Wat die blanke ras betref, kom die "bydrae" van die Indiers daarop neer dat hy stadig maar seker ontwortel (ontbodem) word. Dit moet verhoed word. Wanneer die blanke ras die noue verband met die vaderlandse bodem prysgee, sal dit seker en gewis een van die oorsake wees wat tot sy ondergang in hierdie land sal voer.

As concerns the white race, the "contribution" of the Indian comes down to slowly but surely uprooting [ontbodem, or de-earthing] him. ${ }^{6}$ This must be prevented. When the white race relinquishes its intimate bond with the earth of the Fatherland [Vaderlandse bodem], it will surely and definitely be one of the causes leading to his downfall in this country. (164)

This passage reveals some of Cronjé's anxieties. While ostensibly he is simply talking about Indian South Africans becoming successful farmers in South Africa, at this point in the text, his language returns to this image of Indians as a force that will, "slowly but surely," creep or slip in and force Afrikaners to release their hold on the land. The "intimate bond" with the bodem (earth or soil) is revealed to be reversible, one can be de-earthed [ontbodem], one's claim on the land lost to the "alien" (implicitly revealed here as a fellow alien) South Asian.

Cronjé wants to stress the difference between Indian and European settlers. Tellingly, he concentrates his argument on indentured Indians and their descendants, focusing on whether there was a need to use indentured laborers in the first place. His model for the Indian in South Africa is the indenture contract: a brief, legally controlled interlude, after which s/he is supposed to return to British India. Indians thus never really become a legitimate presence in South Africa-Cronjé wistfully quotes a report by the Indian Immigration Commission in 1909 that (unsuccessfully) recommended that "indentures or contracts of Indians, whether first or subsequent, shall in future terminate in India or upon the high seas ..." (qtd. in Cronjé 33). In order to make this argument in which the Indian never actually becomes a settler, Cronjé switches between legal language and claims (demonstrating an encyclopedic knowledge of laws and reports on Indians in South Africa) and sentimental rhetoric, as we have seen in his stress on the "intimate bond" the Afrikaner has with the soil, for example. In Behold the Earth Mourns, Singh tells a different story about the origins of South Asians in South Africa, emphasizing that her protagonists are the descendants not of indentured laborers, but of traders who built their own shops and developed their own land. However, the specter of the indenture contract and its legal language intrudes into the chronotope of the settler narrative she initially seems to embrace, such that the language of her characters often reflect that of laws regulating the presence of South Asians in South Africa. Thus Yageswari, Srenika's wife, who was born in India, when talking to the clerk selling air tickets who asks her for an "entry permit" for South Africa, replies that "[b]ut my husband was born in South Africa and his parents were domiciled there" (106). Usually, one would simply say his parents "lived" or "resided" in South Africa. However, one of the laws governing the entrance of South Asians into South Africa, the Immigrants Regulation Act (1913), uses the word "domiciled" repeatedly. Yageswari, confronted with a figure of authority (even though this ticket clerk has no legal power), attempts to use the language of the law to her own benefit. 
Singh seems to be aware of the problem of mutually contaminating legal and sentimental rhetoric and even builds it into the text itself, as we saw in the debate she stages between the two brothers, Srenika and Krishnadutt. This is why the ending to this novel is particularly interesting. Initially, it seems like Singh's text wants to frame itself within the chronotope of the traditional settler novel, which is one of genealogical or dynastic descent-the nageslag (posterity) referred to by Cronjé- - one generation succeeding the other and inheriting the land. This chronotope of genealogical descent in the traditional sense is denied to Singh's characters, however, by the imposition of apartheid legislature, which tears the family from their home and thus disrupts the imagined endless time of generation succeeding generation into the future.

Thus the dynastic chronotope is abandoned-but Singh stakes a different kind of filiative claim toward the end of the novel. Yageswari comes back to the house following a jail term for returning to South Africa illegally and sees her daughter, Malini, in the arms of her black African nanny, Anna:

Reluctantly Malini went to her mother almost sensing a strangeness. Yageswari
had neither the strength of emotion nor the energy of the body to receive the
dearest creature of her heart. She smiled in half thankfulness that there was
an attachment- that there should be Anna for her little one. At this moment it
was all she could convey to Anna and she understood it. Anna took her new
child and went into the house, hiding from her the thoughts that passed deep
in her mind. (193)

The novel ends shortly afterwards with the death of Yageswari, leaving the suggestion open that the future of the family lies in this quasi-adoption of Malini by her African nurse, who recedes enigmatically, hiding her thoughts. This is a strange ending to the novel, dedicated "To South Africa on the centenary of the arrival of the Indians in the country" (title page). Is Singh implying that South Africa should be abandoned, given up on as a home for South African Indians? Or is she hinting at the possibility of a new kind of voluntary affiliation, or even filiation, between black and Indian? Crossing racial boundaries that had seemed inviolable, this ending traces a dramatic divergence from both the genealogical association with the soil and the language of law and possession that we have seen to be operative in Singh's and Cronjé's texts.

Another section of the novel suggests a possible reason for this divergence. Yageswari, soon upon her initial arrival in South Africa, attempts to have a conversation with Anna while sketching her portrait:

“Oh Anna. I feel sad. Can I come and see your home?"

"You have to get a paper to come to the farm. The land does not belong to us."

"Then who does it belong to?"

"That is a long story Yagesvari."

"Why did your husband leave you, Anna?"

"This place grow big, big like this."

"Keep your hands down please, Anna."

"I show you all right. More chimneys come, more smoke, and more husbands leave wives."

"But why did he leave you behind?" 
"He can't bring me. He find another woman."

Yagesvari was exasperated. She could not understand. Well she would try another time and went on with her drawing. (146)

As Antoinette Burton also points out in her article "'Every Secret Thing?': Racial Politics in Ansuyah R. Singh's Behold the Earth Mourns," the black characters in the novel are of particular interest. In both these last passages, Anna remains opaque-she "hid[es] ... the thoughts that pass deep in her mind" and here refuses to explain herself clearly to Yageswari. Burton describes this scene by saying that "Yageswari clearly doesn't know about, let alone understand, the township system or the pass laws" (76). While she is right in describing Yageswari's complete inability to understand or connect with Anna here, I would like to add that the system of which she is completely ignorant is not just the pass laws or the township system, but the system of migrant labor in force in South Africa at the time. Starting in the 1870s, African men were recruited to work primarily in mining compounds but later also in factories on short-term contracts. Crucially, they could not bring their families with them and lived in large compounds in hostels close to their place of work. Between contracts they would return to their families, who usually lived in the so-called Native Reserves. The migrant labor system was incredibly disruptive to the family lives of these laborers. The question that Yageswari doesn't understand, why Anna's husband left her, is thus a reference to the fact that he was most likely one of these migrant laborers. "He can't bring me. He find another woman," Anna says-a common fate when migrant laborers spent the vast majority of their time away from their families. Notice also that the "farm" doesn't belong to Anna's family anymore either. The same fate that assails the Nirvani family at the beginning of the novel, the loss of the farm, has happened to Anna's a generation earlier. But this exchange also perhaps hints at something Singh seems to disavow in her novel-the parallels between internal migrant labor in South Africa and the system of indentured labor that brought so many South Asians to South Africa. While at first glance this conversation between Anna and Yageswari seems merely patronizing, both in its content but also in the broken English Singh ascribes to Anna, there is perhaps more at stake here. If indentured labor is written out of Singh's narrative, these covert references to migrant labor, and the fact that Yageswari hands over Malini to Anna at the end of the novel, may be a way to read indenture back into the novel. The filiative connection Yageswari makes with Anna by having her adopt her child could also be an acknowledgement of this alternative history of Indians in South Africa.

Let us compare Singh's novel with the memoir of another South African Indian, Dr. Goonam, which, like the former, privileges passenger Indians over indentured Indians as the protagonists of its narrative. Dr. Goonam, the author of Coolie Doctor: An Autobiography, was born Kesaveloo Goonaruthnum Naidoo in 1906 in Durban. As she explains, "[t]hat made me African, but not quite, for my father had immigrated from South India and my mother from Mauritius" (11). Goonam's descriptions of her childhood home are particularly fascinating to look at alongside Singh's text.

There was a flower garden at the entrance and a large shady tree beneath which my father often sat with his visitors, sipping tea. ... My father also purchased 
a farm about this time. ... I came to love the farm, set against the rolling Natal hills with its sugar cane, and eucalyptus groves, and dipping into the Umgeni River through wooded thickets, slashed red with hibiscus and the amatingula fruit. (17)

The sugar cane on the rolling Natal hills is naturalized, along with the uncultivated eucalyptus groves, hibiscus, and amatingula fruit, so that it seems like all of these things occur without human intervention. This, of course, obscures the question of labor-who established those sugar cane fields, and who harvests them? The members of the family sip tea and entertain visitors, but we don't see who maintains the garden, and who makes the tea. Later in the text Goonam is more forthcoming: "Our attendants were as extra-ordinary as our animals" (19), she says, going on to name Periyar, Narain, and Fakir Chacha as the farm attendants. The only workers named thus seem to be of South Asian descent. As the purchase of the farm takes place around 1927, Periyar, Narain, and Fakir Chacha could no longer be under indenture contracts, but the odds are that they had come over to South Africa as indentured laborers. As Gandhi's biographer, Joseph Lelyveld, points out, in earlier years so-called "Passenger" Indians did on occasion employ indentured laborers: "At least one of [Gandhi's] patrons, a land and property owner named Dawad Mahomed, employed indentured laborers, presumably on the same exploitative terms as their white masters" (14). Even as the Indian laborers eclipse black labor on the farm, Goonam also carefully avoids going into the political and economic circumstances that brought them to South Africa. By comparing them to the farm animals ("our attendants were as extraordinary as our animals"), Goonam is doing the same thing as she does with the sugar cane fields in her description of the farm: the presence of these former indentured laborers is naturalized. Like the farm animals, they simply belong on the farm. Even in this quick comparison between Dr. Goonam's text and Singh's novel, we can see that indentured laborers and the chronotope of the contract play an important though unacknowledged role, haunting the text in distorted forms even as the writers try to erase them from the narrative.

As a counterpoint to this erasure of the history of indenture in South Africa, a fragmentary set of documents from the archives allows us a glimpse into the life of a former indentured laborer, who stayed in South Africa after the expiry of his contract. Studying a series of receipts documenting the purchase of a piece of land outside Ladysmith by one Shingolam/Sewgolam juxtaposes a different kind of contract with the indenture contract: "Memorandum of Agreement made this 26th day of February 1906 between Bhola, Free Indian, of Ladysmith (hereinafter called the seller) of the one part and Shi-ngolam, Free Indian, no. 56934 and Joykandani, his wife, (hereinafter called the purchasers) of the other part" ("L Sewgolam of Ladysmith"). In this document, formerly indentured laborers (Bhola is also referred to as a "free Indian," though he doesn't have a colonial number) become, legally, "Sellers" and "Purchasers" of land: a reclassification that upsets the idea, held up by Cronjé, that these laborers are defined purely by the terms of the indenture contract. A different kind of definition, and with it, a different chronotope, is revealed here. The contract includes the stipulation that the land ("in extent two acres, less a ten feet right of way on the boundary of Lot 81 , and being a subdivision of Lot 82 of the Townlands of Ladysmith") is to be paid off in installments, due on specific dates. 
Here we thus see a different chronotope-both a specific place and time-than that of the indenture contract. At the conclusion of the timeframe specified by this contract, Shingolam/Sewgolam can become the new "Seller" of the piece of land. The rest of this set of documents is a series of receipts, demonstrating that Sewgolam/ Shingolam did finish paying for the land. It is this kind of transaction, and the legal redefinitions implied by it, that the increasingly restrictive and discriminatory statute law of the Union and Republic of South Africa would attempt to render impossible. Goonam's autobiography and Singh's novel are silent on the subject of indentured laborers, seeming to erase the history of the indenture contract and its time limits from the tale of South Asian settlers in South Africa such that this history has to be read between the lines. Shingolam/Sewgolam's contract thus offers us an alternative narrative, a rare story in which formerly indentured laborers play the main role-and in which they become settlers.

I now turn to Gandhi's writings about his time in South Africa, which echo some of the rhetoric of the settler narrative that we see in the beginning of Singh's novel and in Goonam's autobiography.

\begin{abstract}
Sir-You will oblige me by kindly allowing me to say a few words about the Coolie controversy that is being carried on in your paper; not that I want to join the fray but with a view to remove some of the misunderstanding that prevails with regard to the coloured people. The words "Coolie" and "Arab," and especially the latter, are a South African product. Coolie, properly speaking, applies, I understand, to those indentured Indians who have come under the Immigration Act. ... It is clear that Indian is the most proper word for both the classes. ("Letter to the Transvaal Advertiser" 113-14)
\end{abstract}

Thus writes Gandhi in a letter appearing in the Transvaal Advertiser on September 5,1893 , just four months after his arrival in South Africa. Gandhi goes on to say that "[A]ny Indian is a Coolie who has come under the Immigration Act, and ceases to be one when he has finished his agreement" (113). This suggests that, initially at least, Gandhi's understanding of the indentured laborer overlapped with that of imperial lawmakers-not surprisingly, as Gandhi is, of course, a lawyer himself, trained in England. Thus he writes that "no Indian is a Coolie by birth" (113)—one just inhabits the term for a specified, contracted period of time, at the conclusion of which the proper name "Indian" can be reclaimed. Lelyveld begins his biography of Gandhi by saying: "For me the South African Gandhi would always be more than an antecedent, an extended footnote to the fully-fledged Mahatma" (xii). He claims that the final ten months Gandhi spent in South Africa, the period in which he first mobilized Indian indentured laborers to take part in his passive resistance campaigns, "transformed his sense of what was possible for him and those he led" (22). Considering Gandhi's later work on behalf of indentured Indians in South Africa, and also the creation of what Lelyveld refers to as the "standard narrative" of a "figure now generally exalted as a spiritual pilgrim and secular saint" (xiii), it makes sense that this letter, which suggests a more elitist stance, is left out of the standard version of Gandhi's "Collected Works." If Gandhi's attitude shift regarding formerly indentured laborers is as crucial to his development into a "spiritual pilgrim and secular saint" as Lelyveld suggests, it is worth studying this conversion as Gandhi reimagines it in his autobiography, written thirty years after his arrival in South Africa. 
Gandhi, the young lawyer, comes to South Africa at the behest of a wealthy firm, a "Meman firm from Porbander" (Autobiography 88). He initially views his sojourn in South Africa as temporally bounded-he is contracted for " $[\mathrm{n}]$ ot more than a year. We will pay you a first class return fare and a sum of $£ 105$, all round"' (88), he is told in India. I use the term "contracted" deliberately here, though Gandhi makes no specific mention of signing a contract with his new employers. I want to suggest that the time frame of Gandhi's stay in South Africa is perhaps not so different from the time frame of the indentured laborer-a limited temporal and geographic interruption into the lifetime. Gandhi himself says of his initial trip, "This was hardly going there as a barrister. It was going as a servant of the firm" (92; emphasis added). His anxiety is reiterated when he arrives in South Africa and meets his new employer: "He read the papers his brother had sent through me, and felt more puzzled. He thought his brother had sent him a white elephant" (92). Gandhi is "sent" over accompanied by "papers" supposedly legitimizing his presence. Gandhi's excessively dismissive attitude toward indentured laborers, as evidenced by the letter in the Transvaal Advertiser, can thus arguably be explained by his not wanting to be confused with them. His objection is that the term "coolie" is applied indiscriminately to "all coloured men" (113) rather than its proper object, the indentured laborer. This would also explain his insistence not only on traveling first class, but on telling the readers of his autobiography that he traveled first class: "[H]ow could a barrister travel as a deck passenger?" (89), he asks, distinguishing himself not only from the indentured laborers, but also from those Passenger Indians who came over as deck passengers.

Gandhi writes in his autobiography: "I was hence known as a 'coolie barrister.' The merchants were known as 'coolie merchants.' The original meaning of the word 'coolie' was thus forgotten, and it became a common appellation for all Indians" (94). This can be compared to Dr. Goonam's appropriation of the term for her autobiography, Coolie Doctor-both writers are using the term ironically, pointing to the distance between their own circumstances (as well-educated and relatively well-off individuals) and the way they were categorized in race-obsessed South Africa. A later chapter in Gandhi's autobiography, "What It Is to Be a 'Coolie,'” is about his experiences with racial discrimination. Important to note, however, is that all the incidents described in this chapter highlight the distance between Gandhi and a typical indentured laborer, rather than their closeness. In the first case, Gandhi explains how his friend, Mr. Coates, felt uncomfortable issuing a pass for him as he did "to his Negro servants" (112). Rather than do this, he takes Gandhi to his friend, the State Attorney, a Dr. Krause. As it happens, "we turned out to be barristers of the same Inn. ... Instead of ordering for me a pass, he gave me a letter authorizing me to be out of doors at all hours without police interference" (112). In the second case, Gandhi is accosted by a policeman for being too close to the house of the President of the South African Republic, Paul Kruger. His friend Mr. Coates passes by right at that moment and reprimands the policeman: "I could not follow their talk, as it was in Dutch, the policeman being a Boer. But he apologized to me, for which there was no need. I had already forgiven him" (114). Both of these incidents thus stress Gandhi's status as an educated lawyer and his important contacts, men who could shield him from the worst excesses of the discriminatory laws. The chapter heading thus becomes ironic, as he never becomes a "coolie," except through mistaken identity. Gandhi concludes this chapter by 
writing that "the incident deepened my feeling for the Indian settlers" (114). His choice to use the term "settlers" here emphasizes the difference between "coolies" and "settlers" and reveals his desire to identify with the latter.

Gandhi's autobiography, however, also imagines a moment of reconciliation between him and the indentured laborers. While the outright hostility that we see in his letter to the editor of the Transvaal Advertiser is never apparent in the autobiography, indentured laborers initially play no part in his circles of acquaintance. In order to find the source or origin of Gandhi's conversion narrative, I argue, one has to go back to a much earlier passage in the text, when Gandhi describes the death of his father:

It was 10:30 or 11pm. I was giving the massage [to his father]. My uncle offered
to relieve me. I was glad and went straight to the bed-room. My wife, poor thing,
was fast asleep. But how could she sleep when I was there? I woke her up. In five
or six minutes, however, the servant knocked at the door... "Father is no more."
So all was over! ... I saw that, had animal passion not blinded me, I should have
been spared the torture of separation from my father during his last moments. I
should have been massaging him, and he would have died in my arms.... The
shame, to which I have referred in a foregoing chapter, was this shame of my
carnal desire even at the critical hour of my father's death, which demanded
wakeful service. It is a blot I have never been able to efface or forget... Before
I close this chapter of my double shame, I may mention that the poor mite that
was born to my wife scarcely breathed for more than three or four days. Nothing
else could be expected. (26-27)

This is a very far cry from the genealogical model Singh's novel initially seems to espouse. Gandhi's autobiography refuses the cyclical time of reproduction: he is punished for his lust by the death of his child. The intergenerational momentum, in which the living child succeeds and in a sense replaces the dead grandfather, is cut short, "nothing else could be expected." Instead, Gandhi's life arguably becomes a constant attempt to atone for that moment in which he held his wife in his arms, rather than his dying father; a desire to repeat and repair a moment that is past: "It is a blot I have never been able to efface or forget." Much has been written about Gandhi's celibacy, by himself as much as by others, and I am not the first to read this moment in his adolescence as one of the roots of his vow of celibacy, as he indeed implicitly does himself in this passage. ${ }^{7}$ This description, however, also suggests that while every act of lust repeats the act by which he chose to love his wife rather than his father, every act of "nursing" represents Gandhi's reparation for his earlier failure. This repetition can be seen, for example, in the following: on a trip to India, Gandhi becomes a nurse to his brother-in-law. "I put my brotherin-law in my room and remained with him night and day. ... Ultimately, however, the patient died, but it was a great consolation to me that I had had an opportunity to nurse him during his last days" (153). Here Gandhi puts the patient in his own room and stays with him "night and day"-clearly reversing his actions at his father's bedside. It is illuminating that Gandhi refers to him impersonally as "the patient" when he dies. Gandhi repeats the scene of his father's death, but this time, he gets it right: he is by the patient's side when he dies.

Gandhi's first encounter with an individually named indentured laborer is described in his autobiography as follows: 
I had put in scarcely three or four months' practice, and the Congress also was still in its infancy, when a Tamil man in tattered clothes, head-gear in hand, two front teeth broken and his mouth bleeding, stood before me trembling and weeping. He had been heavily belaboured by his master. ... The master, getting angry with him, had lost self-control, and had beaten Balasundaram severely, breaking two of his teeth. (134)

I don't think it too far-fetched to see in this incident an opportunity for Gandhi to exercise his "passion" for nursing. A wounded man comes to the Congress office, "still in its infancy," for help-and this time, Gandhi can help him. The child nurses the father, rather than abandoning him. Gandhi's turn to and eventual championing of indentured laborers can thus be read not as a politically strategic move, but as a moment of reparation within his own developmental arc. This filiative, personal connection allowed Gandhi to care for and help Balasundaram and other "coolies" without sacrificing his claim to a settler identity, which, as we have seen, was still so important to him at the time of writing his autobiography.

In Commerce with the Universe, Desai recognizes a "family resemblance" between the narratives he studies, which he traces to the "mythological charter that often accompanies Indian claims about the community's contributions to East African modernity," a charter that makes the generic switch to "reading commerce as romance rather than conflict" (122). I have argued that we can see the family of writing, both fictional and autobiographical, by writers of South Asian descent living in South Africa as bearing the traces of a different history: that of indenture. These are texts that seek to erase the history of the indenture contract from their claims to legitimate residency and, crucially, land-ownership in reaction to legal statutes that seek to restore the essential temporal conditions of indenture: precarity and impermanence. The genre and chronotope these writers subsequently adopt in their narratives are those of the settler novel-however, they cannot comfortably inhabit this genre, as the texts are repeatedly unsettled by the intrusion of the indenture contract. ${ }^{8}$

\section{NOTES}

1. See Mamdani, When Victims Become Killers, ch. 1, Define and Rule. Desai himself cites Mamdani's inaugural lecture at the University of Cape Town in 1998, "When Does a Settler Become a Native? Reflections of the Colonial Roots of Citizenship in Equatorial and South Africa."

2. For example, Ishtiyaq Shukri, Imraan Coovadia, Achmat Dangor, Shamin Sarif, Farida Karodia, Beverley Naidoo, and other authors all publish novels and short stories in the post-apartheid period.

3. A chronotope is literary time-space, an analytic framework coined by Mikhail M. Bakhtin in "Forms of Time and Chronotope in the Novel."

4. Discriminatory laws began with the $1895 £ 3$ Law (a tax on former indentured laborers who chose to remain in South Africa rather than be repatriated) and the 1897 Immigration Restriction Act of Natal, which was implicitly designed to prevent South Asians from entering the colony. The so-called Asiatic Registration Act (1907) required every "Asiatic" over the age of eight in the Transvaal province to register themselves with the Registrar of Asiatics, completing a Registration Certificate containing their fingerprints. 
5. The earlier law, Law No. 25 of 1891, states: "It shall be lawful for every person entitled to the services of any Indian Immigrant, or for any servant of such person, or for any constable, to apprehend without a warrant such Immigrant being found at a distance of more than one mile from the residence of the person in respect of whom his services shall be due without a written ticket of leave .... Provided that every Indian Immigrant shall be free from such arrest if, when so found, he shall be on his way to lodge any complaint before the Protector of Indian Immigrants, or the Magistrate of the place wherein his place of service is situated" (27).

6. Ontbodem, to de-earth, is used here not in the sense of uncovering but as a negative preposition before the term "earth" or "soil." This is also an uncommon formulation in Afrikaans.

7. See, for example, Parekh, ch. 6; Howard; Lal. Both Howard's book and Lal's article point out that other theorists and biographers of Gandhi, including William L. Shirer and Sudhir Kakar, have also identified this, his father's death, as a key moment in Gandhi's psychobiography, shaping his relationship to sex and celibacy.

8. I thank my fellow participants at the 2015 Writing South Africa Now conference, held at the University of Cambridge, for their comments and questions, as well as Mark Sanders for his feedback on earlier versions of this article.

\section{WORKS CITED}

"Act No. 1, 1897." Immigration (Restricted), Statutes of Natal, 1845-1899, vol. 1, edited by R. L. Hitchens and G. W. Sweeney, P. Davis and Sons, 1900.

Bakhtin, M. M. "Forms of Time and Chronotope in the Novel." The Dialogic Imagination: Four Essays by M.M. Bakhtin, edited by Michael Holquist, translated by Caryl Emerson and Michael Holquist, U of Texas P, 1981, pp. 84-258.

Burton, Antoinette. “'Every Secret Thing'? Racial Politics in Ansuyah R. Singh's Behold the Earth Mourns." The Journal of Commonwealth Literature, vol. 46, no. 1, 2011, pp. 63-81.

Chanock, Martin. The Making of South African Legal Culture, 1902-1936: Fear, Favour and Prejudice. Cambridge UP, 2001.

Coetzee, J. M. “The Mind of Apartheid: Geoffrey Cronjé (1907-).” Social Dynamics, vol. 17, no. 1, 1991, pp. 1-35.

White Writing: On the Culture of Letters in South Africa. Yale UP, 1988.

Cronjé, Geoffrey. Afrika Sonder die Asiaat: Die Blywende Oplossing van Suid-Afrika se Asiatevraagstuk. Publicite Handelsreklamediens (EDMS) Bpk., 1946.

Desai, Gaurav. Commerce with the Universe: Africa, India and the Afrasian Imagination. Columbia UP, 2013.

Gandhi, Mohandas K. Autobiography: The Story of my Experiments with Truth, translated by Mahadev Desai, Dover Publications, Inc., 1983.

"Letter to the Transvaal Advertiser," September 5, 1893. Rpt. in The South African Gandhi. An Abstract of the Speeches and Writings of M.K. Gandhi, 1893-1914, edited by Fatima Meer, Madiba Publishers, 1996, pp. 113-14.

Goonam, Dr. (Kesaveloo Goonaruthnum Naidoo). Coolie Doctor: An Autobiography. Madiba Publishers for Institute for Black Research, 1991.

Hofmeyr, Isabel. "Africa as a Fault Line in the Indian Ocean." Eyes Across the Water: Navigating the Indian Ocean, edited by Pamila Gupta, Isabel Hofmeyr, and Michael Pearson, Unisa Press, 2010, pp. 99-108.

Howard, Veena R. Gandhi's Ascetic Activism: Renunciation and Social Action. SUNY Press, 2013. 
"Immigrants Regulation Act (Act No. 22 of 1913)." Statutes of the Union of South Africa 1913. Printed under the Superintendence of the Government Printer, 1913.

Lal, Vinay. "Nakedness, Nonviolence and Brahmacharya: Gandhi's Experiments in Celibate Sexuality." Journal of the History of Sexuality, vol. 9, nos. 1-2, 2000, pp. 105-36.

"Law No. 25, 1891." "To amend and consolidate the Laws relating to the Introduction of Indian Immigrants into the Colony of Natal, and to the regulation and government of such Indian Immigrants" [3rd September, 1891]. Statutes of Natal, 18451899, vol. 1, edited by R. L. Hitchens and G. W. Sweeney, P. Davis and Sons, 1900.

Lelyveld, Joseph. Great Soul: Mahatma Gandhi and His Struggle with India. Vintage, 2012.

"L. Sewgolam of Ladysmith-Transfer Documents." 1270/194-218. South African National Archives Repository, Pretoria, South Africa.

Mamdani, Mahmood. Define and Rule: Native as Political Identity. Harvard UP, 2012.

When Victims Become Killers: Colonialism, Nativism, and the Genocide in Rwanda. Princeton UP, 2001.

Morton, J. “Mango." Fruits of Warm Climates. Purdue University, 1987. https://hort .purdue.edu/newcrop/morton/mango_ars.html.

Parekh, Bhikhu. Colonialism, Tradition and Reform: An Analysis of Gandhi's Political Discourse. Sage Publications Ltd., 1989.

Singh, Ansuyah R. Behold the Earth Mourns. Cape Times Limited, 1960.

"Trial of the Naidoos and Others for Picketing." Indian Opinion, 1908. Rpt. in The South African Gandhi. An Abstract of the Speeches and Writings of M. K. Gandhi, 1893-1914, edited by Fatima Meer, Madiba Publishers, 1996, pp. 718-19. 
Copyright of Research in African Literatures is the property of Indiana University Press and its content may not be copied or emailed to multiple sites or posted to a listserv without the copyright holder's express written permission. However, users may print, download, or email articles for individual use. 